\title{
ANALISIS HOME INDUSTRI KERUPUK OPAK DI DESA JAYA BAKTI KECAMATAN MADANG SUKU I KABUPATEN OKU TIMUR
}

\author{
(Parmaji)
}

\begin{abstract}
The purpose of this research is to: (1) to know the technique of making opak crackers in Jaya Village Bakti Madang Suku I District of East OKU Regency, (2) Knowing the income and breakeven from opak cracker home industry in Jaya Bakti Village Madang Suku I District OKU East, (3) Knowing the added value of opak cracker home industry in Jaya Bakti Village, Madang Suku I District, OKU Timur Regency, (4) Find out if home industry of opak crackers in Jaya Bakti Village, Madang Suku I District OKU Timur is beneficial and feasible to be developed. This research was conducted in April to June 2014 at opak cracker home industry conducted by Ibu Suratmi in Jaya Bakti Village Madang Suku I District of East OKU Regency. Determining the location of the research is done purposively with the consideration that there are still not many who do opak cracker home industry, whereas raw materials are widely available. This research found that the technique of making opak crackers is easy enough that by cassava grated, seasoned (garlic, coriander and salt), then printed and steamed for \pm 2 minutes for once steaming opak crackers, then dried for \pm 2 days, after Crude cracker crackers are packed and then marketed. So, the process of making opak crackers takes \pm 5 days. Receipt from home opal cracker manufacture industry is $R p$ 735.000, - / PP, with production cost $R p$ 501.362, - / PP, with fixed cost of Rp. 69.444, - / PP and variable cost of 428.000, - / $P P$ then the revenue is obtained $R p 233.638$.- / PP or Rp 1.401.828.- / Month. Value added on opak cracker manufacture amounted to $R p$. 333,638, - / PP obtained from the proceeds minus intermediate expenses. The intermediate cost is obtained from the total production cost of Rp. 501,362, - / PP minus family labor cost of Rp. 100.000, - / PP so the total cost between Rp. 401.362, - / PP and profit rate based on the receipt of the value of more than 1 is $R / C$ Ratio of 1.47 which means that opa cracker home industry is profitable. While based on the rate of profit from income is more than the prevailing bank interest rate is $B$ / C Ratio of 0.47 which means home industry of non-feasible opak crackers. BEP production value of Rp. 53,27, - / kg / PP, BEP value of acceptance of Rp. 559.361, - / PP, and the value of BEP price of Rp. Rp. 4.386, - / kg / PP, so that this business can be considered functionally feasible. In addition, the total assets invested for home industry for a year or ROI value generate a profit of $0.38 \%$, which means for home industry opak cracker manufacture for one year to produce profit / profit of $0.38 \%$.
\end{abstract}

Key Words : Agroindustry, Home Industry, Value-added, Feasibility.

\section{PENDAHULUAN}

\section{A. Latar Belakang}

Pembangunan sektor industri secara nasional diarahkan untuk mendorong terciptanya struktur ekonomi yang seimbang dan kokoh yang meliputi aspek perubahan ekonomi. Fokus perhatian pembangunan sektor ekonomi perlu diberikan pada subsektor industri kecil dan kerajinan yang memiliki potensi dan peranan penting. Keberadaan industri kecil dan kerajinan yang sebagian besar di daerah pedesaan tentunya memberikan sumbangan bagi daerahnya. Agribisnis bersama agroindustri merupakan pendekatan yang ditempuh untuk pengembangan pertanian industri pada masa yang akan datang. Hal tersebut dikarenakan industry pengolahan hasil pertanian (agroindustri) yang ditangani secara utuh, mulai dari proses produksi, mengolah hasil, pemasaran, dan aktivitas lain yang berkaitan dengan kegiatan pertanian (agribisnis) bukan saja mampu sebagai sumber pertumbuhan baru bagi sector pertanian, akan tetapi juga mampu menyerap banyak tenaga kerja dan nilai tambah (Aristanto, 2006).

Menurut Masyhuri (2004), tingkat perkembangan sektor industri di Indonesia masih relatif rendah, akan tetapi pengembangan industri kecil bukan saja bagi suatu jalur ke arah pemerataan hasil-hasil pembangunan, melainkan juga sebagai unsur pokok dari seluruh struktur industri di Indonesia yang dengan investasi kecil, dapat berproduksi secara efektif serta dapat menyerap tenaga kerja. Peranan dan strategi dari industri kecil dalam perekonomian sangat erat kaitannya dengan industri kecil itu sendiri yang terdiri dari 5 komponen sebagai berikut: 
1. Industri kecil pada umumnya bersifat local labour insetive, yang berarti industri kecil sangat mengandalkan pada penggunaan tenaga kerja yang berasal dari sekitarnya (tenaga kerja lokal).

2. Industri kecil sangan intensif dalam pemakaian sumber-sumber alam lokal.

3. Industri kecil banyak dijumpai di daerah pedesaan.

4. Industri kecil sangat erat hubungannya dengan sektor pertanian.

5. Sebagian besar industri kecil membuat barangbarang konsumsi dan industri untuk memenuhi kebutuhan pasar lokal dengan tingkat harga yang terjangkau terutama bagi kalangan masyarakat yang berpenghasilan menengah ke bawah.

Sedangkan, sektor pertanian dalam wawasan agribisnis melalui perannya dalam ekonomi pertanian memberikan beberapa hal yang menunjukan keunggulan yang dapat dipertimbangkan. Keunggulan tersebut antara lain nilai tambah pada agroindustri misalnya dengan cara pembuatan kerupuk opak, dimana pendapatan yang diperoleh menjadi lebih besar dibandingkan dengan ubi kayu yang langsung dipasarkan tanpa terlebih dahulu dilakukan pengolahan. Akan tetapi, kebanyakan agroindustri yang ada pada saat ini masih berskala kecil dan rumah tangga, dengan penggunaan tekhnologi yang masih sederhana serta kepemilikan modal yang terbatas, sehingga produksi yang dihasilkan belum memadai secara kualitas maupun kuantitas (Sumardi, 2003).

Ubi kayu adalah salah satu bahan pangan yang utama tidak saja di Indonesia tetapi di dunia, di Indonesia ubi kayu merupakan makanan pokok ketiga setelah padi-padian dan jagung. Sedangkan, untuk konsumsi penduduk dunia khususnya penduduk negara-negara tropis setiap tahun diproduksi sekitar 300 juta ton ubi kayu. Selain itu, sekitar $45 \%$ dari total produksi ubi kayu dunia langsung dikonsumsi oleh produsen sebagai sumber kalori. Kebutuhan produksi ubi kayu dunia, diperkirakan akan terus meningkat, dan untuk mencukupi kebutuhan ubi kayu nasional diperlukan program peningkatan produksi persatuan luas lahan, perbaikan kualitas, serta pengolahan hasil panen (Djaafar dkk, 2003).

Produksi ubi kayu nasional meningkat karena memiliki potensi dan prospek yang baik untuk diusahakan, khususnya salah satu kabupaten yang ada di Provinsi Sumatera Selatan yaitu Kabupaten OKU Timur. Data dari Dinas Pertanian Tanaman Pangan dan Holtikultura
Kabupaten OKU Timur Tahun 2014. Luas tanaman ubi kayu \pm 2.120 ha dengan luas tanaman panen \pm 2.016 ha dengan rata-rata produksi kedelai sebanyak \pm 35.372 ton/ha, seperti terlihat pada tabel berikut:

Tabel 1. Jumlah Lahan dan Hasil Pertanian Tanaman Pangan Kabupaten OKU Timur.

\begin{tabular}{|c|c|c|c|c|}
\hline \multirow{2}{*}{$\begin{array}{l}\text { Tanaman } \\
\text { Pertanian }\end{array}$} & \multicolumn{4}{|c|}{ Jumlah Lahan dan Hasil Pertanian } \\
\hline & Luas Tanah (ha) & $\begin{array}{l}\text { Luas Panen } \\
\text { (ha) }\end{array}$ & $\begin{array}{l}\text { Produksi } \\
\text { (ton) }\end{array}$ & $\begin{array}{l}\text { Rata-rata } \\
\text { (ton /ha) }\end{array}$ \\
\hline Padi Sawah & 144.586 & 132.113 & 725.987 & 5,50 \\
\hline Padi Ladang & 1.911 & 1.911 & 4.130 & 2,16 \\
\hline Jagung & 9.230 & 9.208 & 62.910 & 6,83 \\
\hline Kacang Kedelai & 1.285 & 933 & 926 & 0,99 \\
\hline Kacang Tanah & 339 & 339 & 504 & 1,49 \\
\hline Kacang Hijau & 67 & 67 & 85 & 1,27 \\
\hline Ubi Kayu & 2.120 & 2.016 & 35.372 & 17,55 \\
\hline Ubi Jalar & 121 & 116 & 1.018 & 8,78 \\
\hline
\end{tabular}

Sumber: Dinas Tanaman Pangan dan Holtikultura Kabupaten OKU Timur.

Salah satu penyebab meningkatnya produksi ubi kayu di Kabupaten OKU Timur adalah karena banyak terdapat industri baik industri yang berskala besar maupun industri yang berskala yang kecil seperti industri rumahan (home industri), yang mengolah ubi kayu menjadi berbagai jenis makanan. Produk makanan hasil olahan dari ubi kayu antara lain ubi kayu rebus, ubi kayu bakar, ubi kayu goreng, tela-tela, kolak, keripik, kerupuk opak, tape, tepung tapioka, bioethanol, gaplek dan lain-lain. Salah satu home industri yang ada di Kabupaten OKU Timur adalah home industri pembuatan opak yang ada di Desa Jaya Bakti.

Akan tetapi, home industri pembuatan kerupuk opak masih mengalami beberapa kendala antara lain pangsa pasar, permodalan dan pengembangan usaha. Kendala pasar yang dihadapi yaitu sulitnya menerobos pasar karena produksi yang masih rendah, sehingga menunggu pembeli datang ke tempat usaha. Sedangkan, kendala modal yang dihadapi dalam home industri pembuatan kerupuk opak antara lain untuk pembelian peralatan produksi yang lebih modern, karena tekhnologi yang digunakan dalam pembuatan kerupuk opak masih tradisional yang berdampak pada produksi kerupuk opak.

\section{B. Rumusan Masalah}

1. Bagaimanakah tekhnik pembuatan kerupuk opak di Desa Jaya bakti Kecamatan Madang Suku I Kabupaten OKU Timur.

2. Berapa besar pendapatan dari home industri kerupuk opak di Desa Jaya Bakti Kecamatan Madang Suku I Kabupaten OKU Timur. 
3. Berapa nilai tambah dari home industri kerupuk opak di Desa Jaya Bakti Kecamatan Madang Suku I Kabupaten OKU Timur.

4. Bagaimana tingkat kelayakan home industri kerupuk opak di Desa Jaya Bakti Kecamatan Madang Suku I Kabupaten OKU Timur.

\section{Tujuan dan Kegunaan}

1. Mengetahui tekhnik pembuatan kerupuk opak di Desa Jaya bakti Kecamatan Madang Suku I Kabupaten OKU Timur.

2. Mengetahui pendapatan dan titik impas dari home industri kerupuk opak di Desa Jaya Bakti Kecamatan Madang Suku I Kabupaten OKU Timur.

3. Mengetahui nilai tambah dari home industri kerupuk opak di Desa Jaya Bakti Kecamatan Madang Suku I Kabupaten OKU Timur.

4. Mengetahui apakah home industri kerupuk opak di Desa Jaya Bakti Kecamatan Madang Suku I Kabupaten OKU Timur menguntungkan dan layak untuk dikembangkan.

\section{Model Pendekatan}



Gambar 1. Model pendekatan penelitian secara diagramatik

\section{METODOLOGI PENELITIAN}

\section{A. Tempat dan Waktu}

Penelitian ini telah dilaksanakan pada Bulan April sampai dengan Bulan Juni tahun 2014 pada home industri kerupuk opak yang dilakukan oleh Ibu Suratmi di Desa Jaya Bakti Kecamatan Madang Suku I Kabupaten OKU Timur. Penentuan lokasi penelitian dilakukan secara sengaja (purposive) dengan pertimbangan bahwa masih belum banyak yang melakukan home industri kerupuk opak, padahal bahan baku banyak tersedia.

\section{B. Metode Penelitian}

Metode penelitian yang digunakan adalah metode case study, metode ini dapat digunakan untuk mengamati data dan masalah yang dapat dijadikan objek penelitian. Menurut Umar (2003), metode studi kasus adalah sebuah metode penelitian yang secara khusus menyelidiki fenomena kontemporer yang terdapat dalam kontek kehidupan yang nyata, dan dilaksanakan ketika batasan menggunakan berbagai sumber data dalam kaitannya dengan waktu dan tempat home industri kerupuk opak di Desa Jaya Bakti Kecamatan Madang Suku I.

\section{Metode Penarikan Contoh}

Metode penarikan contoh yang digunakan adalah metode sensus. Menurut Zulkarnain (2005), metode sensus adalah metode dimana pengambilan sampel dilakukan secara sengaja terhadap 1 populasi dan sekaligus menjadi responden yaitu pelaku home industri kerupuk opak di Desa Jaya Bakti Kecamatan Madang Suku I Kabupaten OKU Timur.

\section{Metode Pengolahan Data}

Data yang diperoleh dari penelitian dikelompokan, kemudian diolah secara tabulasi yaitu menghitung besarnya biaya produksi, penerimaan, pendapatan, R/C Ratio, B/C Ratio, nilai tambah, BEP Produksi, BEP Harga, BEP Penerimaan dan ROI home industri kerupuk opak, dengan rumus sebagai berikut:

1. Untuk menjawab tujuan yang pertama yaitu mengetahui tekhnik pembuatan kerupuk opak di Desa Jaya bakti Kecamatan Madang Suku I Kabupaten OKU Timur, dilakukan dengan cara wawancara langsung dengan pelaku home industri kerupuk opak serta pengamatan dilapangan mengenai pembuatan kerupuk opak.

2. Untuk menjawab tujuan yang ke dua yaitu mengetahui pendapatan dan titik impas dari home industri kerupuk opak di Desa Jaya Bakti Kecamatan Madang Suku I Kabupaten OKU Timur. Maka rumus matematis yang digunakan adalah sebagai berikut:

a)Menurut Suratiyah (2006), untuk mengetahui biaya produksi maka digunakan rumus:

$\mathrm{TC}=\mathrm{FC}+\mathrm{VC}$

Dimana:

$\mathrm{TC}=$ Total Cost $($ Total Biaya $)$

$\mathrm{FC}=$ Fixed Cost (Biaya Tetap)

$\mathrm{VC}=$ Variabel Cost $($ Biaya Tidak Tetap) 
b) Menurut Suratiyah (2006), untuk mengetahui besarnya penerimaan maka digunakan rumus:

$\mathrm{R}=\mathrm{Y} \times \mathrm{P}$

Dimana:

$\mathrm{R}=$ Revenue (Penerimaan)

$\mathrm{Y}=$ Yield (Hasil Produksi)

$\mathrm{P}=$ Price (Harga)

c)Menurut Suratiyah (2006), untuk mengetahui besarnya pendapatan maka digunakan rumus:

$\mathrm{I}=\mathrm{R}-\mathrm{TC}$

Dimana:

$\mathrm{I}=$ Income (Pendapatan)

$\mathrm{R}=$ Revenue (Penerimaan)

$\mathrm{TC}=$ Total Cost $($ Total Biaya)

3. Untuk menjawab tujuan yang ke tiga yaitu mengetahui nilai tambah dari home industri kerupuk opak di Desa Jaya Bakti Kecamatan Madang Suku I Kabupaten OKU Timur. Menurut Bambang dan Rahayu (2010), nilai tambah dapat dihitung dengan menggunakan rumus:

$\mathrm{NT}=\mathrm{TR}-\mathrm{IC}$

\section{Dimana:}

NT= Nilai Tambah

$\mathrm{TR}=$ Total Revenue $/$ Total Penerimaan

$\mathrm{IC}=$ Intermediate Cost/Biaya Antara.

4. Untuk menjawab tujuan yang ke empat yaitu mengetahui tingkat keuntungan dan kelayakan home industri kerupuk opak di Desa Jaya Bakti Kecamatan Madang Suku I Kabupaten OKU Timur.Maka rumus matematis yang digunakan adalah sebagai berikut:

1) Menurut Suratiyah (2006), untuk mengetahui tingkat keuntungan dalam penerimaan digunakan rumus:

$\mathrm{R} / \mathrm{C}$ Ratio $=\frac{\mathrm{TR}}{\mathrm{TC}}$

Dimana:

$\mathrm{R} / \mathrm{C}$ Ratio = Ratio Perbandingan antara Total Penerimaan (Total Revenue) dan Biaya (Cost)

$\mathrm{TR}=$ Total Revenue $($ Total Penerimaan)

$\mathrm{TC}=$ Total Cost $($ Total Biaya $)$

Kriteria:

$\mathrm{R} / \mathrm{C}>1$ maka usaha menguntungkan

$\mathrm{R} / \mathrm{C}<1$ maka usaha tidak menguntungkan $\mathrm{R} / \mathrm{C}=1$ maka usaha impas

2) Menurut Suratiyah (2006), untuk mengetahui tingkat keuntungan dalam pendapatan digunakan rumus sebagai berikut:

$\mathrm{B} / \mathrm{C}$ Ratio $=\frac{\pi}{\mathrm{TC}}$

Dimana:
$\mathrm{B} / \mathrm{C}$ Ratio $=$ Ratio Perbandingan antara Keuntungan $\left(\mathrm{P}_{\mathrm{hi}}\right)$ dan Total Biaya (Total Cost)

$\mathrm{B}=$ Benefit $($ Manfaat $) \rightarrow \pi=\mathrm{P}_{\mathrm{hi}}$

$\mathrm{TC}=$ Total Cost $($ Total Biaya)

Kriteria:

B/C > Suku bunga bank yang berlaku maka usaha menguntungkan (feasible)

B/C $<$ Suku bunga bank yang berlaku maka usaha tidak menguntungkan (Non feasible)

$\mathrm{B} / \mathrm{C}=$ Suku bunga bank yang berlaku maka usaha impas

3) Menurut Suratiyah (2006), Analisis Break Event Point Produksi (BEP Produksi) digunakan untuk menghitung berapa produksi agar memperoleh keuntungan, dengan rumus:

BEP $($ Produksi $)=\frac{\text { FC }}{\text { P-AVC }}$

Dimana:

$\mathrm{FC}=$ Fixed Cost (Biaya Tetap)

$\mathrm{P}=$ Price $($ Harga $)$

$\mathrm{AVC}=$ Average Variable Cost ( Rata-rata Biaya Tidak Tetap)

4) Menurut Suratiyah (2006), Analisis Break Event Point Harga (BEP Harga) digunakan untuk menghitung berapa harga jual, agar memperoleh keuntungan di atas total biaya produksi atau keuntungan dari total biaya produksi yang telah dikeluarkan, dengan rumus:

BEP $($ Harga $)=\frac{T C}{Y}$

Dimana:

$\mathrm{TC}=$ Total Cost $($ Total Biaya Produksi $)$

$\mathrm{Y}=$ Yield (Produksi)

5) Menurut Suratiyah (2006), Analisis Break

Event Point Penerimaan (BEP Penerimaan) digunakan untuk menghitung besarnya penerimaan agar memperoleh keuntungan, dengan rumus:

$$
\mathrm{BEP}(\text { Penerimaan })=\frac{\mathrm{FC}}{1-\frac{\mathrm{VC}}{\mathrm{TR}}}
$$

Dimana:

$\mathrm{FC}=$ Fixed Cost (Biaya Tetap)

$\mathrm{VC}=$ Variable Cost (Biaya Variabel)

$\mathrm{TR}=$ Total Revenue (Total Penerimaan)

6) Menurut Danang (2014), analisis Return On Investmen (ROI) bertujuan untuk mengetahui tingkat pengembalian total harta yang digunakan untuk menghasilkan laba. Semakin tinggi nilai ROI, maka kondisi usaha akan semakin baik, hal 
tersebut dikarenakan laba usaha akan cenderung meningkat, dengan rumus:

ROI $=\frac{\text { Laba Usaha }}{\text { Total harta }} \times 100 \%$

Dimana:

$\begin{aligned} \text { ROI }= & \begin{array}{l}\text { Return On Investmen } \\ \text { Pengembalian Modal) }\end{array}\end{aligned}$

Laba Usaha = Pendapatan dikurangi dengan biaya tenaga kerja keluarga

Total Harta $=$ Modal keseluruhan ditambah dengan biaya tenaga kerja dan total investasi.

\section{HASIL DAN PEMBAHASAN}

\section{A. Analisis Home Industri Pembuatan Kerupuk Opak.}

\section{Proses Pembuatan Kerupuk Opak}

Pelaku home industri pembuatan kerupuk opak melakukan kegiatan setiap 3 (tiga) hari sekali, dengan bahan baku konsisten yaitu $100 \mathrm{~kg}$ ubi kayu. Hal tersebut dikarenakan untuk menjaga kapasitas pemasaran, apabila jumlah kerupuk opak yang dihasilkan melebihi kapasitas pemasaran maka yang terjadi ditingkat pemasaran mengalami kesulitan. Bahan baku yang digunakan untuk pembuatan kerupuk opak adalah ubi kayu yang berasal dari daerah sendiri (lokal) dan dibeli langsung melalui pemesanan. Proses pembuatan kerupuk opak dilakukan dengan cara diparut dengan penjelasan sebagai berikut:

a. Bahan-bahan yang digunakan:

1) Ubi kayu (100 kg)

2) Bawang putih $(1 / 4 \mathrm{~kg})$

3) Ketumbar 1 ons

4) Garam secukupnya

b. Alat-alat yang digunakan untuk membuat kerupuk opak:

1) Pisau 2 buah

2) Bak 3 buah

3) Parutan 2 buah

4) Panci (untuk mengukus) 1 buah

5) Tutup panci (5 buah)

6) Kompor dan gas 1 buah

7) Jemuran (terbuat dari bambu dengan panjang $\pm 15 \mathrm{~m}$ sebanyak 2 jemuran)

8) Setrimin $\pm 30 \mathrm{~m}$

c. Proses pembuatan kerupuk opak

1) Ubi kayu dikupas kemudian diparut

2) Campu parutan ubi kayu dengan bawang putih,ketumbar dan garam sudah dihaluskan.

3) Setelah adonan menyatu, ambil seukuran kepalan tangan, kemudian dibuat menjadi tipis-tipis di atas tutup panci dengan bentuk bulat menipiskan adonan cukup menggunakan atau bisa juga menggunakan batu (penumbuk/ulekan lemper).

4) Kerupuk opak yang sudah dicetak, diletakan di atas plastik dan selanjutnya dikukus selama \pm 2 menit, kemudian kerupuk opak diangkat diganti dengan yang baru dan dikukus kembali, begitu seterusnya sampai adonan habis.

5) Kerupuk opak yang sudah dikukus selanjutnya disusun dirak tempat penjemuran yang sudah dilapisi setrimin, dengan tujuan agar mudah dalam pengangkatan dan agar kerupuk yang patah tidak jatuh ke tanah.

6) Kerupuk opak dijemur langsung di bawah sinar matahari selama \pm 2 hari dengan panas yang baik, agar kerupuk opak ketika digoreng dapat mengembang dengan sempurna, selain itu kerupuk opak memiliki daya simpan yang lebih lama, karena tidk dengan mudah ditumbuhi jamur.

7) Selanjutnya kerupuk opak yang sudah kering diangkat dari jemuran dan disusun masing-masing sebanyak \pm 35 lembar (1 $\mathrm{kg}$ ) serta diikat dengan menggunakan tali yang berasal dari bambu.

8) Kerupuk opak siap untuk dipasarkan dengan harga rata-rata Rp. $10.500,-/ \mathrm{kg}$ (Rp. 300,-/biji).

Ubi kayu sebanyak $100 \mathrm{~kg}$ yang telah diparut, diberi bumbu, dan dicetak menjadi \pm 70 $\mathrm{kg}$ ( \pm 2.450 lembar). Salah satu kendala yang dihadapi oleh pelaku home industri pembuatan kerupuk opak selama ini adalah alat yang digunakan masih bersifat tradisiomal, sehingga produksi yang dihasilkan belum maksimal. Produksi yang belum maksimal, maka pemasaran kerupuk opak belum memiliki pangsa pasar yang luas. Selain itu, pelaku home industri pembuatan kerupuk opak belum memiliki modal yang cukup, walaupun bahan baku berupa ubi kayu banyak tersedia. Bahan baku berupa ubi kayu yang selama ini pelaku home industri pembuatan kerupuk opak gunakan adalah berasal dari daerah sekitar, hal tersebut dikarenakan selain memanfaatkan potensi yang ada, harga ubi kayu juga relatif lebih murah dan kualitas tetap terjamin. Sedangkan kendala lain yang dihadapi adalah pemasaran kerupuk opak yang belum luas, oleh sebab itu para pelaku home industri pembuatan kerupuk opak sangat mengharapkan peran pemerintah dalam mempromosikan kerupuk opak kepada masyarakat umum. 


\section{Total Biaya Produksi (Total Cost)}

Menurut Djuwari (2004), biaya produksi adalah semua pengeluaran yang dilakukan oleh perusahaan untuk faktor-faktor produksi, sehingga memperoleh output. Sedangkan, menurut Sumardi (2003), biaya produksi adalah semua pengorbanan yang perlu dilakukan oleh produsen/perusahaan untuk suatu proses produksi, yang dinyatakan dengan satuan uang menurut harga pasar yang berlaku, baik yang sudah terjadi maupun yang akan terjadi. Biaya ini berada posisi yang harus seefesien mungkin agar mempunyai keuntungan yang optimal.

Biaya tetap adalah biaya yang tidak habis dalam satu kali proses produksi, yaitu biaya sewa tempat usaha pembuatan kerupuk opak dan total biaya penyusutan alat. Sedangkan biaya variabel adalah biaya yang habis dalam satu kali proses produksi, diantaranya biaya sarana produksi dan tenaga kerja. Biaya sarana produksi antara lain bahan baku (ubi kayu), bumbu-bumbu (bawang putih, ketumbar, dan garam), serta gas lpj.

Tabel 2. Rincian Biaya Produksi Home Industri Pembuatan Kerupuk Opak Perproses Produksi.

\begin{tabular}{llr}
\hline No. & \multicolumn{1}{c}{ Uraian } & $\begin{array}{c}\text { Pelaku Home Industri } \\
\text { Kerupuk Opak (Rp/PP) }\end{array}$ \\
\hline 1. & Biaya Tetap & $73.362,-$ \\
& - Sewa Tempat Usaha & $69,444,-$ \\
& - Biaya Penyusutan Alat (BPA) & $3.918,-$ \\
\hline 2. & Biaya Variabel & $428.000,-$ \\
& - Biaya Sarana Produksi & $178.000,-$ \\
& - Biaya Tenaga Kerja & $250.000,-$ \\
\hline 3. & Total Biaya & $501.362,-$ \\
\hline
\end{tabular}

Sumber: Data Primer (Diolah), 2014.

Berdasarkan tabel di atas diketahui rata-rata besarnya biaya tetap yang dikeluarkan oleh pelaku home industri adalah Rp. 69.444,-/PP yang digunakan untuk sewa tempat usaha Rp. 69,444,dan biaya penyusutan alat Rp. 3.918,-/PP. Selain biaya tetap pelaku home industri juga mengeluarkan biaya variabel sebesar Rp. 428.000,-/PP diantaranya untuk biaya sarana produksi sebesar Rp. 178.000,-/PP serta untuk biaya tenaga kerja mulai dari pembersihan bahan baku, pemarutan, penyetakan, pengukusan, penjemuran dan pengemasan sebesar Rp. 250.000/PP,-. Sehingga total dari keseluruhan biaya yang dikeluarkan oleh pelaku usaha selama satu kali poses produksi ( \pm 5 hari sekali/ $6 \mathrm{x}$ dalam 1 Bulan) adalah jumlah dari biaya tetap ditambah dengan jumlah biaya variabel maka total biaya produksi adalah Rp. 501.362,-/PP.

\section{Produksi, Penerimaan, Pendapatan \\ Perproses Produksi}

Berdasarkan hasil penelitian di lapangan produksi, penerimaan dan pendapatan pelaku home industri kerupuk opak perproses produksi dapat di lihat pada tabel berikut ini:

Tabel 3. Rincian Produksi, Penerimaan, dan Pendapatan Pelaku Home Industri Pembuatan Kerupuk Opak Perproses Produksi.

\begin{tabular}{|c|c|}
\hline No. Uraian & Pelaku Home Industri Kerupuk Opak \\
\hline 1. Bahan Baku (Ubi kayu) & $100 \mathrm{~kg} / \mathrm{PP}$ \\
\hline 2. Produksi (Kerupuk opak) & $70 \mathrm{~kg} / \mathrm{PP}$ \\
\hline 3. Harga (Kerupuk Opak) & $10.500,-/ \mathrm{kg}$ \\
\hline 4. Total Biaya Produksi & Rp. $501.362,-/ P P$ \\
\hline 5. Penerimaan & Rp. $\quad 735.000,-/ P P$ \\
\hline 6. Pendapatan & Rp. 233.638,-/PP (Rp. 1.401.828,-/Bulan) \\
\hline
\end{tabular}

Sumber: Data Primer (Diolah), 2014.

Pelaku home industri kerupuk opak mampu menghasilkan kerupuk opak $70 \mathrm{~kg}$ rata-rata sebanyak 35 lembar/kg (2.450 lembar/PP) dengan harga Rp. 10.500,-/kg (Rp. 300,-/lembar). Harga akan mempengaruhi besarnya penerimaan pelaku home industri, oleh sebab itu pelaku home industri lebih banyak yang memilih menjual kerupuk opak hasil produksi di rumah/tempat usaha, kecuali jika tidak habis maka kerupuk opak dijual di pasar, akan tetapi selama ini kerupuk opak selalu habis terjual di rumah/tempat usaha.

Menurut Swastha (2001), penerimaan adalah jumlah penghasilan produksi dalam satuan fisik dikalikan dengan harga jual, yang didefinisikan sebagai nilai uang yang diterima. Penerimaan yang diterima oleh pelaku home industri kerupuk opak adalah sebesar Rp. 735.000,-/PP (Proses Produksi), sedangkan biaya produksi yang dikeluarkan adalah Rp. 501.362,./PP. Besarnya biaya produksi yang dikeluarkan akan mempengaruhi pendapatan yang diterima oleh pelaku home industri. Besarnya pendapatan yang diperoleh adalah Rp. 233.638,-/PP (Rp. 1.401.828,-/Bulan). Pendapatan yang lebih besar merupakan alasan bagi pelaku usaha untuk menambah cadangan sebuah usaha baru.

\section{Analisis Nilai Tambah}

Analisis nilai tambah home industri pembuatan kerupuk opak dilakukan untuk mengetahui besarnya nilai yang ditambahkan pada bahan baku yang digunakan dalam memproduksi kerupuk opak. Analisis nilai tambah kerupuk opak dengan produk akhir yang diterima adalah nilai yang diberikan atau dijual dari pelaku home industri kepada konsumen. Biaya antara yang dikeluarkan pelaku home industri merupakan biaya yang digunakan untuk pembelian bahan lain yang digunakan selain bahan baku yaitu bumbubumbu (bawang putih, ketumbar, dan garam). Semakin besar nilai tambah yang diperoleh maka akan semakin besar juga keuntungan yang 
diperoleh pelaku home industri begitu juga sebaliknya.

Tabel 4. Nilai Tambah Home Industri Kerupuk Opak Perproses Produksi.

\begin{tabular}{clc}
\hline No. & \multicolumn{1}{c}{ Uraian } & Home Industri Kerupuk Opak Rp $P P$ \\
\hline 1. & Penerimaan & $735.000,-$ \\
2. & Biaya Produksi & $501.362,-$ \\
3. & Tenaga Kerja Keluarga & $100.000,-$ \\
4. & Biaya Antara & $401.362,-$ \\
5. & Nilai Tambah & $333.638,-$ \\
\hline
\end{tabular}

Sumber: Data Primer (Diolah), 2014.

Nilai tambah pada pembuatan kerupuk opak sebesar adalah Rp. 333.638,-/PP yang diperoleh dari penerimaan dikurangi biaya antara. Biaya antara diperoleh dari total biaya produksi yaitu Rp. 501.362,-/PP dikurangi biaya tenaga kerja keluarga sebesar Rp. 100.000,-/PP sehingga total biaya antara adalah Rp. 401.362,-/PP.

\section{Kelayakan Home Industri Kerupuk Opak}

Home industri kerupuk opak setelah dilakukan analisis perhitungan dan kunjungan di lapangan maka dapat dikatakan layak karena berdasarkan segi ekonomi memiliki keuntungan, seperti pada tabel berikut:

Tabel 5. Tingkat Kelayakan Home Industri Kerupuk Opak Perproses Produksi.

\begin{tabular}{clr}
\hline No. Uraian & Pelaku Home Industri Pembuatan Kerupuk Opak \\
\hline 1. & RC Ratio & 1,47 \\
2. & B/C Ratio & 0,47 \\
3. & Produksi & $70 \mathrm{~kg}$ \\
4. & Harga & Rp. $10.500,-/ \mathrm{kg}$ \\
5. & BEP Produksi & $16,73 \mathrm{~kg}$ \\
6. & BEP Harga & Rp. $6.114,-/ \mathrm{kg}$ \\
7. & BEP Penerimaan & Rp. $175.638,-/ \mathrm{PP}$ \\
8. & ROI & $0,38 \%$ \\
\hline
\end{tabular}

Sumber: Data Primer (Diolah), 2014.

Tingkat keuntungan berdasarkan penerimaan nilainya lebih dari 1 yaitu R/C Ratio sebesar 1,47 yang artinya home industri kerupuk opak tersebut menguntungkan. Sedangkan berdasarkan tingkat keuntungan dari pendapatan nilainya lebih dari suku bunga bank yang berlaku yaitu B/C Ratio sebesar 0,47 yang artinya home industri pembuatan kerupuk opak non feasibel. Nilai R/C Ratio sebesar 1,47 artinya setiap satu rupiah yang dikorbankan akan memperoleh penerimaan sebesar Rp. 1,47,-, sedangkan nilai B/C Ratio sebesar 0,47 berarti setiap satu rupiah yang dikorbankan akan diperoleh pendapatan atau keuntungan sebesar Rp. 0,47,-. Sehingga home industri kerupuk opak tersebut menguntungkan tetapi belum feasibel.

Home industri kerupuk opak dengan nilai BEP produksi 16,73 kg/PP. Hal tersebut menunjukan bahwa ketika produksi kerupuk opak sudah mencapai $16,73 \mathrm{~kg} / \mathrm{PP}$ maka home industri tersebut mencapai titik impas. Hasil penelitian menunjukan bahan produksi yaitu $70 \mathrm{~kg}$, maka akan diperoleh keuntungan sebesar Rp. 53,27,$/ \mathrm{kg} / \mathrm{PP}$, sehingga usaha ini dapat dikatakan layak secara fungsional.

Home industri kerupuk opak dengan nilai BEP penerimaan Rp. 175.639,-/PP. Hal tersebut menunjukan bahwa ketika penerimaan home industri kerupuk opak sudah mencapai Rp. 175.639,-/PP, maka home industri tersebut mencapai titik impas. Hasil penelitian menunjukan penerimaan home industri kerupuk opak sebesar Rp.735.000,-/PP, maka akan diperoleh keuntungan sebesar Rp. 559.361,-/PP, sehingga usaha ini dapat dikatakan layak secara fungsional.

Sedangkan home industri kerupuk opak dengan nilai BEP harga Rp. 10.500,-/kg/PP (lampiran 14). Hal tersebut menunjukan bahwa ketika harga produksi sudah mencapai Rp. 6.114,-$/ \mathrm{kg} / \mathrm{PP}$, maka home industri tersebut mencapai titik impas. Hasil penelitian menunjukan harga kerupuk opak sebesar Rp. 10.500,-/kg/PP, maka akan diperoleh keuntungan sebesar Rp. 4.386,-$/ \mathrm{kg} / \mathrm{PP}$, sehingga usaha ini dapat dikatakan layak secara fungsional. Selain itu, total harta yang diinvestasikan untuk home industri selama setahun atau nilai ROI menghasilkan laba sebesar $0,38 \%$, artinya untuk home industri pembuatan kerupuk opak selama satu tahun menghasilkan laba/keuntungan sebesar $0,38 \%$.

\section{IV.KESIMPULAN DAN SARAN}

\section{A. Kesimpulan}

Berdasarnya hasil penelitian dan analisis yang telah dilakukan, maka dapat ditarik kesimpulan sebagai berikut:

1. Teknik pembuatan kerupuk opak cukup mudah yaitu dengan cara ubi kayu diparut, diberi bumbu (bawang putih, ketumbar dan garam), kemudian dicetak dan dikukus selama \pm 2 menit untuk sekali pengukusan kerupuk opak, selanjutnya dijemur selama \pm 2 hari, setelah kerupuk opak mentah kering dikemas dan kemudian baru dipasarkan. Jadi, proses pembuatan kerupuk opak membutuhkan waktu \pm 5 hari.

2. Penerimaan yang diperoleh dari home industri pembuatan kerupuk opak adalah sebesar $\mathrm{Rp}$ 735.000,-/PP, dengan biaya produksi Rp 501.362,-/PP, dengan biaya tetap sebesar Rp. 69.444,-/PP dan biaya variabel sebesar 428.000,-/PP maka diperoleh pendapatan 
sebesar Rp 233.638.-/PP atau Rp 1.401.828./Bulan.

3. Nilai tambah pada pembuatan kerupuk opak sebesar adalah Rp. 333.638,-/PP yang diperoleh dari penerimaan dikurangi biaya antara. Biaya antara diperoleh dari total biaya produksi yaitu Rp. 501.362,-/PP dikurangi biaya tenaga kerja keluarga sebesar $\mathrm{Rp}$. $100.000,-/ \mathrm{PP}$ sehingga total biaya antara adalah Rp. 401.362,-/PP.

4. Tingkat keuntungan berdasarkan penerimaan nilainya lebih dari 1 yaitu R/C Ratio sebesar 1,47 yang artinya home industri kerupuk opak tersebut menguntungkan. Sedangkan berdasarkan tingkat keuntungan dari pendapatan nilainya lebih dari suku bunga bank yang berlaku yaitu B/C Ratio sebesar 0,47 yang artinya home industri pembuatan kerupuk opak non feasibel. Nilai BEP produksi sebesar Rp. 53,27,-/kg/PP, nilai BEP penerimaan sebesar Rp. 559.361,-/PP, dan nilai BEP harga Rp. Rp. 4.386,-/kg/PP, sehingga usaha ini dapat dikatakan layak secara fungsional. Selain itu, total harta yang di investasikan untuk home industri selama setahun atau nilai ROI menghasilkan laba sebesar $0,38 \%$, artinya untuk home industri pembuatan kerupuk opak selama satu tahun menghasilkan laba/keuntungan sebesar $0,38 \%$.

\section{B. Saran}

Berdasarkan hasil pembahasan dan kesimpulan yang ada di atas maka saran yang dapat diberikan oleh peneliti adalah:

1. Pelaku home industri kerupuk opak sebaiknya membudidayakan sendiri ubi kayu sehingga persedian bahan baku terjamin.

2. Pelaku home industri kerupuk opak harus tetap menjaga kualitas produk yang dihasilkan dengan tetap memperhatikan kualitas bahan baku yang digunakan serta menambah skala produksi dan meragamkan rasa dari kerupuk opak sehingga dapat meningkatkan pendapatan.

3. Sebaiknya pelaku home industri kerupuk opak tidak hanya memasarkan kerupuk opak mentah tetapi juga yang sudah siap dikonsumsi.

4. Pelaku home industri kerupuk opak sebaiknya melegalkan produknya, sehingga dapat mencapai pasar luas dengan cepat. Sedangkan untuk pemerintah diharapkan dapat memberikan kemudahan dalam mengurus perizinan dan memberikan perhatian yang lebih sehingga kendala yang selama ini dihadapi oleh pelaku home industri pembuatan kerupuk opak sedikit demi sedikit dapat teratasi.

\section{DAFTAR PUSTAKA}

Arsyad, L. 2003. Ekonomi Manajerial. Edisi Kelima. Balai Pustaka. Yogyakarta.

Aristanto. 2006. Pemberdayaan Usaha Kecil. Science Journal No: 25 Desember. Universitas Merdeka. Malang.

Bambang Y.D. dan Rahayu, R. 2010. Jumlah Sistem Agribisnis Terintegrasi Hulu-Hilir. Muara Indah. Bandung.

Dinas Tanaman Pangan dan Holtokultura. 2014. Jumlah Lahan dan Hasil Pertanian. Kabupaten OKU Timur. Sumatera Selatan.

Djaafar, et all. 2003. Ubi Kayu dan Olahannya. Kanisius. Yogyakarta.

Djuwari. 2004. Aspek-aspek Ekonomi Usaha Tani. Program Pasca Sarjana. UGM. Yogyakarta.

Ibrahim, Y. 2009. Study Kelayakan Bisnis. Rineka. Jakarta.

Joersan. 2003. Teori Ekonomi Mikro. Salemba Empat. Jakarta.

Kartasapoetra. 2000. Dasar-dasar Ilmu Usaha Tani. LP3ES. Jakarta.

Kusnadi. 2006. Studi Kelayakan Bisnis. Universitas Bramawijaya. Malang.

Kuswadi. 2007. Analisis Keekonomian Proyek. Andi Offset. Yogyakarta.

Manullang. 2003. Analisis Harga. LP3ES. Jakarta.

Masyhuri. 2004. Pengembangan Agroindustri Melalui Penelitian dan Pengembangan Produk yang Intensif dan Berkesinambungan dalam Journal Agro Ekonomi Vol VII / No. 1 Juni / 2000. Jurusan Sosial Ekonomi Pertanian Fakultas Pertanian UGM. Yogyakarta.

Mulyadi. 2007. Akuntansi Biaya, Edisi Kelima. Graha Ilmu. Yogyakarta.

Munawir, S. 2005. Analisis Kriteria Investasi. Gunadarma. Jakarta.

Prasasto, S. 2008. Tekhnik pembuatan Kerupuk Ubi Kayu. http://WordPress.com. diakses pada hari selasa tanggal 11 Maret 2014.

Rahardjo, P. 2006. Transformasi Pertanian, Industrialisasi dan Kesempatan Kerja. UI Press. Jakarta.

Sudarsono. 2003. Pengantar Ekonomi Mikro. LP3ES. Yogyakarta.

Sudiyono. 2004. Kelayakan Usaha. Balai Pustaka. Yogyakarta. 
Sumardi. 2003. Pengantar Ekonomi Pertanian. PT. Bumi Aksara. Jakarta.

Suratiyah, K. 2006. Ilmu Usaha Tani. Penebar Swadaya. Jakarta.

Suprapto. 2005. Ekonomi Produk Pertanian. BPK Fakultas Pertanian. Surakarta

Swastha, B. 2001. Azaz-azaz Marketing, Edisi ke lima. Liberty. Yogyakarta.

Sjarkowi, F dan Marwan, S. 2004. Manajemen Agribisnis. CV. Baldad Grafitti Press. Palembang.

Sjarkowi, F. 2010. Manajemen Pembangunan Agribisnis. CV. Baldad Grafitti Press. Palembang.
Tambunan, T. 2009. Perekonomian Industri Skala Kecil di Indonesia. PT. Mutiara Sumber Widya.

Tarigan, R. 2004. Ekonomi Regional. Bumi Aksara. Jakarta.

Todaro, M. P. 2004. Pembangunan Ekonomi Dunia Ketiga Jilid 2. Erlangga.Jakarta.

Zakaria, W.A. 2000. Analisis Nilai Tambah Ubi Kayu pada Beberapa Agroindustri Berbasis Ubi Kayu di Propinsi Lampung. Jurnal Ilmiah sosial ekonomi Pertanian. Vol 6 (2): 122-123. 